\title{
THE DESIGN OF MINIMUM VIABLE MARKETING STRATEGY FOR RESEARCH-BASED INNOVATION PRODUCT (CASE STUDY PT RUMAH RUMPUT LAUT)
}

\author{
Noorisiva Larasati*)1, Idqan Fahmi*), and Agustina Widi Palupiningrum* ${ }^{*}$ \\ *) School of Business, IPB University \\ Jl. Pajajaran, Bogor 16151, Indonesia
}

\begin{abstract}
The PT Rumah Rumput Laut (PT RRL) start-up in researched-based innovation produces healthy cosmetics. The high-quality standard based on innovation were not followed by the demand side. Limited market and decreasing demand for products require the strategy to survive in the cosmetics industry. This study aims to 1) evaluate the performance of PT RRL's marketing mix, 2) analyze attributes that are important for cosmetics consumers, 3) analyze and formulate a Minimum Viable Marketing strategy design that can be applied to PT RRL. Data were collected by using a questionnaire through a survey to the internal and external (consumer and potential customer) stakeholders. The analysis was conducted with descriptive approach, IPA techniques, and benchmarking to see the assessment of the level of importance and level of performance of PT RRL products. The results showed that the internal and external stakeholders' views about the level of importance were not matched. In addition, the attributes of the co-creation, currency, communal activation and conversation variables were the focus of improvement in the company's Minimum Viable Marketing design. The focused attributes were discovered by implementing the BCD Strategy, which utilized website and e-mail as a marketing foundation, supported by an amplification channel that activated social media and the digital community.
\end{abstract}

Keywords: cosmetic, importance and performance level, marketing mix, minimum viable marketing, strategic management

\begin{abstract}
Abstrak: Perusahaan start-up PT Rumah Rumput Laut (PT RRL) bergerak dalam bidang inovasi berbasis riset menghasilkan produk kosmetik yang sehat. Standar berkualitas tinggi hasil inovasi nyatanya tidak diikuti oleh sisi permintaan. Pasar yang terbatas dan permintaan produk yang menurun membutuhkan strategi untuk bertahan di industri kosmetik. Penelitian ini bertujuan untuk 1) mengevaluasi kinerja marketing mix PT RRL, 2) menganalisis atribut yang penting bagi konsumen pengguna kosmetik, 3) menganalisis dan merumuskan desain strategi Minimum Viable Marketing yang dapat diterapkan pada PT RRL. Data dikumpulkan dengan menggunakan kuesioner melalui survei kepada pihak internal dan eksternal (konsumen dan calon konsumen potensial). Analisis dilakukan dengan pendekatan deskriptif, teknik IPA, dan benchmarking untuk melihat penilaian terhadap tingkat kepentingan dan tingkat kinerja produk PT RRL. Hasil penelitian menunjukkan bahwa pandangan pihak internal dan eksternal tentang tingkat kepentingan tidak cocok. Selain itu, atribut co-creation, currency, communal activation dan conversation menjadi fokus perbaikan dalam desain Minimum Viable Marketing perusahaan. Atribut-atribut tersebut ditemukan dengan menerapkan Strategi $B C D$, yaitu menggunakan situs web dan email sebagai fondasi pemasaran, didukung oleh amplification channel yang mengaktifkan media sosial dan komunitas digital.
\end{abstract}

Kata kunci: kosmetik, tingkat kepentingan dan tingkat kinerja, bauran pemasaran, minimum viable marketing, manajemen strategik

${ }^{1}$ Corresponding author:

Email: noorisivalarasati@apps.ipb.ac.id 


\section{INTRODUCTION}

Most universities in Indonesia still use an innovation model with a technology push approach (Ameka \& Dewanto, 2013) that requires a strong enough pull from the market to ensure the success of innovation activities. Through the Technology-Based Start-Up Company Candidate Program for Higher Education (CPPBT-PT), the Ministry of Research, Technology, and Higher Education carries out efforts to foster PPBT in developing and encouraging innovation results towards downstream and commercialization. This program is intended for lecturers and students as part of cultivating an entrepreneurial spirit in higher education.

PT Rumah Rumput Laut (PT RRL) is one of the startups that processes seaweed innovatively into the form of healthy cosmetic products, especially skincare with the Wedlyn brand. PT RRL was established in 2017, and the company has successfully gotten grant funds from the CPPBT-PT Ministry of Research, Technology, and Higher Education. The products of PT RRL are the result of innovation based on the scientific approach from IPB University. The products received awards in the Most Prospective Indonesian Innovation according to the Business Innovation Centre in 2015. PT RRL has also been covered by several national television stations and received offers to cooperate in manufacturing beauty products made from seaweed. Now, many of PT RRL's seaweed-processed cosmetic products have spread throughout Indonesia. However, behind these fantastic achievements, the company currently faces problems in marketing and sales. There was a significant decrease in sales volume in 2019 compared to 2018, even though the cosmetics industry is considered demanding at present, especially for products with the concept of back to nature which should be an opportunity for the company. The significant decrease in sales volume from 2018 to 2019 can be seen in Table 1 .

As of early 2020, the company has not received corporate development grant funds from the Ministry of Research, Technology, and Higher Education. This means PT RRL must develop and compete in the industry independently. However, the company will obtain a distribution permit from the Food and Drug Supervisory Agency (BPOM), get Good Cosmetics Manufacturing Practices (CPKB) certification, launch four new products, and start exporting to Qatar early 2020. Obtaining the BPOM distribution permit and the CPKB certification indicate that the opportunity to compete in the cosmetic industry is even more open, and companies can massively expand product distribution.

Table 1 Product sales volume of PT RRL (2018-2019)

\begin{tabular}{|c|c|c|}
\hline \multirow{3}{*}{ Types of Products } & \multicolumn{2}{|c|}{ Amount sold (pcs) } \\
\hline & 2018 & 2019 \\
\hline & $\begin{array}{l}\text { (January - } \\
\text { December) }\end{array}$ & $\begin{array}{l}\text { (January - } \\
\text { December) }\end{array}$ \\
\hline Seaweed Blackmask & 4080 & 2355 \\
\hline Seaweed Honey mask & 3540 & 1489 \\
\hline Seaweed Aloemask & 3480 & 1566 \\
\hline Seaweed Supercream & 1980 & 1098 \\
\hline $\begin{array}{l}\text { Seaweed Hand \& Body } \\
\text { Lotion }\end{array}$ & 2040 & 839 \\
\hline Seaweed Lipbalm & 672 & 217 \\
\hline Seaweed Pomade $40 \mathrm{gr}$ & 720 & 495 \\
\hline Seaweed Pomade 85 gr & 420 & 15 \\
\hline
\end{tabular}

The decrease in product sales volume can be caused by many reasons. To find the cause can be seen from the internal and external environment of the company with a framework of marketing mix 4C (co-creation, currency, communal activation, and conversation) and IPA (Important Performance Analysis). According to Wijayanti (2017), the marketing mix results from a collaboration of four elements, namely products, prices, promotions, and distribution. Every element has different roles and functions but is one inseparable unity with each other. In a world of mutually connected today, to accommodate more consumers, it needs to be supported by an even more developed marketing mix to match the era. According to Kotler et al. (2017), the 4P marketing mix can be defined re-become a marketing mix of 4.0 (4C) consisting of co-creation, currency, communal activation, communal conversations, and conversations.

Aziz's research (2019) was to analyze the importance and performance of the teahouse marketing mix. In analyzing the framework of the teahouse marketing mix, Aziz (2019) uses a product development marketing mix involving consumers, otherwise known as the $4 \mathrm{C}$ marketing mix consisting of co-creation, currency, communal activation, and conversation. The use of the $4 \mathrm{C}$ marketing mix is considered more in line with the development of the times. Therefore, Aziz's research (2019) is relevant because this study uses the IPA method and $4 \mathrm{C}$ marketing mix framework. 
Furthermore, the research conducted by Widiastuti (2012), the purpose of the study is to analyze factors such as brand, price, product quality, packaging design, service quality, and store layout that affect consumer satisfaction in the use of skincare products. The research advised players in the cosmetics industry to develop skincare products that suit the wants and needs of consumers. Therefore, Widiastuti's research (2012) has relevance to this research in providing advice to PT RRL to develop its products under the wants and needs of consumers.

Furthermore, in the research conducted byAfianti(2019), one of the objectives of the research was to formulate a marketing strategy of PT Intidaya Agrolestari (Inagro) with benchmarking analysis against its competitors who are considered as leaders in the agro-tourism industry at Bogor regency. Information about the performance of similar institutions was also used as learning towards improving Inagro performance. Therefore, Afianti research (2019) has relevance to this research in benchmarking, wherein this study was conducted benchmarking with Ocean Fresh.

The difference between this research and the three previous studies lies in the research object and collaboration of the methods used. Aziz's research uses teahouse and Afianti research using agro-tourism companies for his research objects, while this research uses cosmetic companies as research objects. Then for this study using the combined method by Aziz and Afianti, namely combining IPA with the framework of 4C marketing mix and benchmarking, the combining of methods is intended to give a comprehensive strategy.

Martilla and James (1977) mention the IPA techniques used to evaluate existing marketing and develop marketing strategies. In this research, IPA was used to evaluate the marketing mix. It is necessary to analyze the importance and performance of each attribute of the marketing mix by both internal and external parties of companies. So, the $4 \mathrm{C}$ marketing mix is used as a framework, and IPA is used as an evaluator to see a perspective gap between internal and external parties related to PT RRL products. The hypothesis is that there is a perspective gap between internal and external parties related to PT RRL products. Based on these, three research questions will cover this study: 1 . How is the performance of PT RRL's marketing mix?; 2. How do cosmetic users respond to the attributes that are emphasized?;3. What is the minimum viable marketing design that can be applied to PT RRL?. To answer those questions, this research aims to make a Minimum Viable Marketing design that can be applied in the company based on internal and external company evaluations.

\section{METHODS}

Data collection and processing were carried out from April to May 2020 in Bogor, Indonesia. Respondents from external company parties consist of consumers and potential customers. The internal respondents were the commissioner and the director of PT RRL. In this case, the commissioner is also the inventor of the research product. The external respondent consists of 91 respondents, where 69 respondents were customers of PT RRL, and 23 respondents were potential customers.

Simultaneously, collecting data and information collection techniques for this research are literature study, interviews, and questionnaires. Interviews with the founder of PT RRL were done to find out the company's current state and future expectations. The technique of determining the respondents used in this study was non-probability sampling using convenience sampling. Accordingly, this study used descriptive analysis methods, Importance Performance Analysis (IPA), and benchmarking analysis. The initial stage of data analysis in this study is descriptive analysis qualitative processed based on a $4 \mathrm{C}$ marketing mix to explain the marketing management conditions of the company as well as how consumer preferences cosmetic products as well as Wed. 4C marketing mix model is felt more done in terms of marketing because the model has the inline with marketing philosophy and consumer behavioral science. $4 \mathrm{C}$ marketing mix has consumer-oriented properties and emphasizes customer satisfaction (Ali et al. 2019). The next stage uses the Importance Performance Analysis technique (IPA); Martilla and James (1977) mention the IPA technique used to evaluate existing marketing and develop marketing strategies. In IPA techniques, respondents assessed the importance and level of performance of the products offered by a company which then averages the value analyzed in the Importance \& Performance Matrix. Importance \& Performance Matrix has four quadrants. The quadrants include concentrate here, keep up the good work, low priority, and possible overkill (Martilla and James, 1977)(Figure 1). 
The next stage is benchmarking analysis, where the priority attributes of the three respondents' IPA become the basis for the comparison made against similar companies to get an idea of what the company has done. The comparison is certainly enriching inspiration for the minimum viable marketing design of PT Rumah Rumput Laut.

The framework in the research can be seen in Figure 2. The internal analysis is carried out by analyzing the condition of the company's marketing manager and assessing the level of importance and performance of the internal part of the company. Meanwhile, the external analysis is carried out by assessing the level of importance and performance of consumers and potential consumers as well as doing benchmarking analysis of the marketing mix. The actual picture related to the current condition of the company's marketing manager and gaps between internal and external perceptions as the results of appraising the marketing mix and benchmarking will be the direction and inspiration for constructing an appropriate Minimum Viable Marketing design for PT RRL.

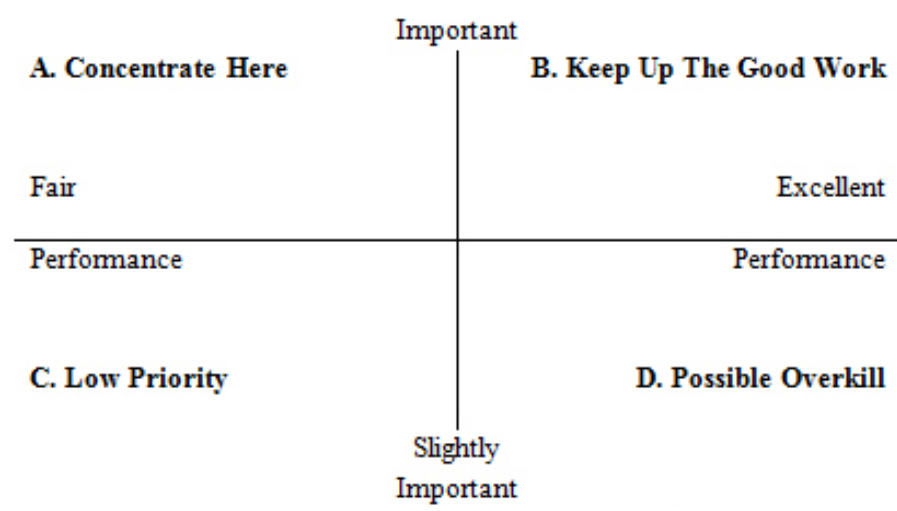

Figure 1. IPA Cartesian Diagram (Martilla and James, 1977)

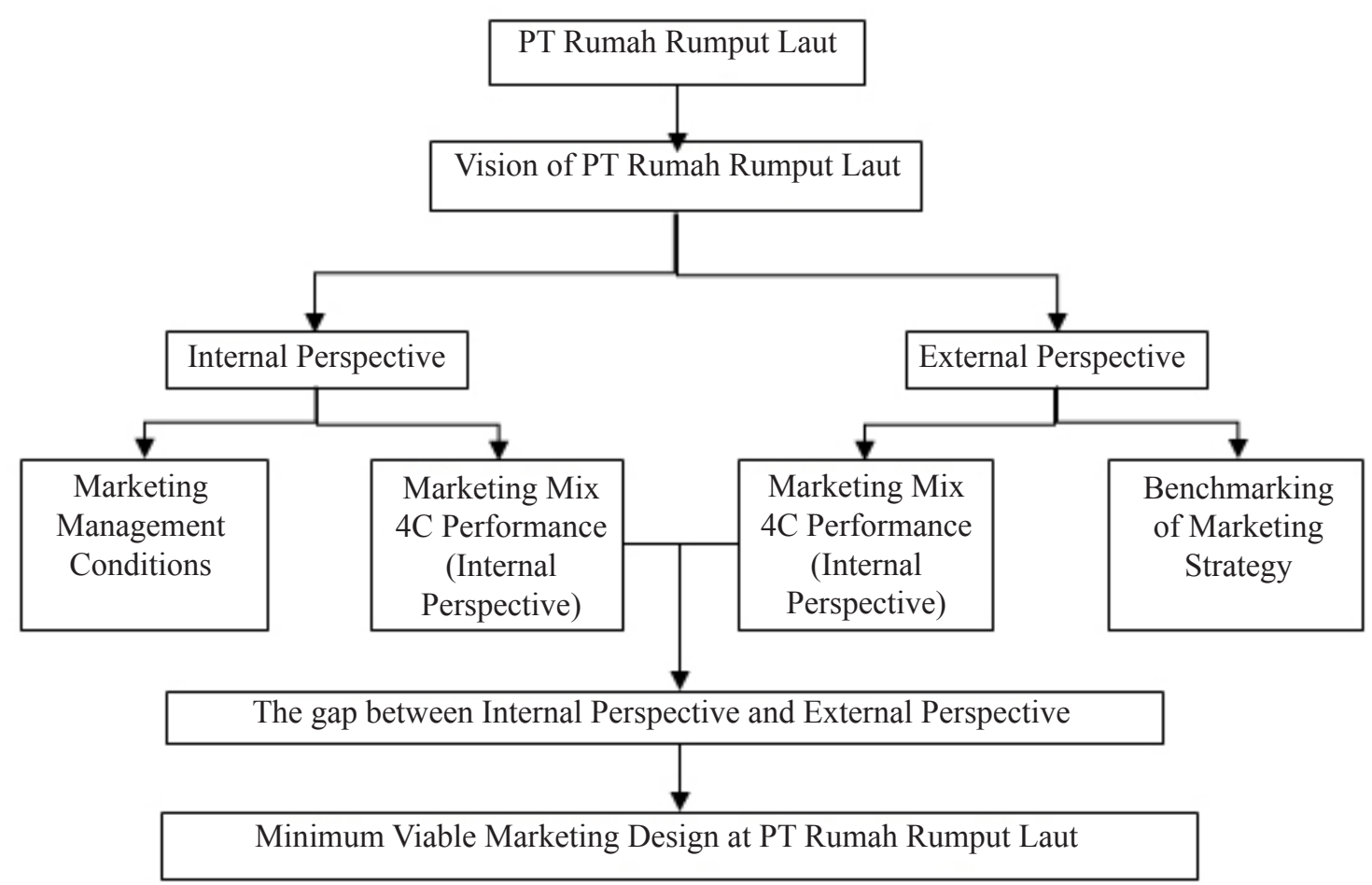

Figure 2. Research framework 


\section{RESULTS}

The customer respondent showed that $81 \%$ of the PT RRL were female, on the age of 19-35 years old (92\%). The occupation of the respondents in this study were students (70\%), employers (21\%), and housewives $(9 \%)$. The income of the respondents $<1.000 .000$ $(42 \%), 1.000 .000-2.500 .000(42)$ and $>2.500 .000$ $(16 \%)$.

According to Kotler and Keller (2009), marketing management is the activity of analyzing plans related to actualization and control of planned programs to produce good exchanges in a market that has been targeted and following company goals. In general, the 4P marketing mix (product, price, place, and promotion) is still very much attached to PT RRL. The 4P marketing mix is a marketing mix that focuses on product development from the producer side. In identifying customer needs, tastes, and preferences, PT RRL research up-to-date trends in the market, the results of which are tested on students or lecturers. As previously stated, PT RRL's products are the result of innovations from the professor of THP IPB, Prof. Nurjanah. Due to time and cost constraints, product-market tests are conducted on IPB students and lecturers known by inventors in the campus area. The company places great importance on product quality, but product prices remain competitive with other products.

\section{Attribute Performance Improvement Priority}

To reach a wider market and increase sales return, the evaluation of PT RRL's marketing mix from internal and external perspectives (potential consumers and potential customers) is expected to understand what area has been well assessed and what needs to be improved. Improving performance is the priority attribute found at Quadrant I of the IPA cartesian diagram to be effective and efficient in terms of time and cost. The $4 \mathrm{C}$ criteria and attributes can be seen in Table 2 .

Table 2. 4C Criteria and Attributes

\begin{tabular}{|c|c|c|}
\hline 4C Criteria & & Attributes \\
\hline \multirow[t]{12}{*}{ Co-Creation } & $(1)$ & BPOM product distribution license \\
\hline & $(2)$ & Product halal certification \\
\hline & (3) & The basic ingredients of the product \\
\hline & (4) & Product benefits \\
\hline & $(5)$ & Innovative products \\
\hline & (6) & Suitability of product variants with skin types \\
\hline & (7) & Product safety \\
\hline & $(8)$ & Variants of product sizes \\
\hline & $(9)$ & The withdrawal of product packaging \\
\hline & $(10)$ & Product packaging makes it easy to use the product \\
\hline & $(11)$ & Product packaging makes product storage easier \\
\hline & $(12)$ & Range of product-specific packages \\
\hline \multirow[t]{3}{*}{ Currency } & $(13)$ & Suitability of price with consumer purchasing power \\
\hline & $(14)$ & Competitive price \\
\hline & $(15)$ & Membership levels \\
\hline \multirow[t]{2}{*}{ Communal Activation } & $(16)$ & Ease of finding products offline \\
\hline & $(17)$ & Ease of finding products online \\
\hline \multirow[t]{3}{*}{ Conversation } & $(18)$ & a means of communication between consumers \\
\hline & $(19)$ & a means of communication between consumers and companies \\
\hline & $(20)$ & Proactively respond to consumers \\
\hline
\end{tabular}


Furthermore, IPA calculation is done by calculating the average value of importance level and the average performance level value. The interpretation of the IPA diagram is as follows:

\section{- Quadrant I (Concentrate Here)}

This quadrant shows attributes that have belowaverage performance levels but have above average importance levels. The attributes in this quadrant are priorities that must be improved.

- Quadrant II (Keep Up the Good Work)

This quadrant shows attributes that have aboveaverage levels of performance and importance. Companies are obliged to maintain the attributes in this quadrant.

- Quadrant III (Low Priority)

This quadrant shows attributes that have a belowaverage level of importance and performance level. Companies need to improve the performance of attributes in this quadrant, but the priority is still below quadrant A because the effect is small for consumers.

- Quadrant IV (Possible Overkill)

This quadrant shows attributes that have aboveaverage performance levels but below average levels of importance by consumers. Companies can reduce or allocate existing resources to focus on improving quadrant I to save costs.

\section{Internal Company Category}

This research focuses on improving the attributes that need to be improved, therefore focus on quadrant I. In quadrant I, the importance level of cosmetic products is above average, while Wedlyn's performance level is still below average. Therefore, in this quadrant are attributes that become a priority to be improved based on the internal perspective of the company (Figure 2). The attribute included in quadrant I is product safety (7), where the company feels the resulting product is still considered to be less than the standard of safety according to company standards. In contrast, Wedlyn uses natural ingredients that have been laboratory tested in its manufacture, which means the products produced are safe and do not cause side effects or irritation. It may also indicate that there are consumers who complain of incompatibility; if there are side effects, it can occur because of incompatibility in the skin type, not because of the basic ingredients of the product. Facial skin is classified into several types, including normal, combination, oily, dry, and sensitive skin (Irawati, 2013). Different types of consumer skin make the main reason consumers look for cosmetic products with variants that match their skin type so that the product works optimally, while the use of certain variants, although claimed to be suitable for all skin types, in fact, can cause incompatibility or irritation of the skin. This is what the company needs to pay attention to. In addition, the attributes of product size variants (8), where the company feels with the current size that is one size on all Wedlyn products except on pomade that there are two sizes, small sizes used for end consumers, and large sizes for barbershop businesses, is not enough to meet the needs of consumers. This needs to be reviewed based on the consumer's evaluation of whether consumers need and want those attributes. Furthermore, the attribute of membership level (15), where the company feels membership or membership in its system needs to be improved. So far, the company applies membership level only for its B2B activities, while for its $\mathrm{B} 2 \mathrm{C}$ activities, the company does not have a membership system. Of course, it needs to be reviewed whether the company needs these attributes to meet consumers' needs.

\section{Consumer Category}

This research focuses on improving the attributes that need to be improved, therefore focus on quadrant I. In quadrant I, the level of interest in cosmetic products is considered important by consumers, but the implementation performance of PT RRL still does not meet the customer's wishes (Figure 3). Therefore, in this quadrant is the attributes that become a priority to be improved. Attributes included in quadrant I is the suitability of product variants with skin types (6) where the product variants offered by PT RRL are still intended for all skin types, when in fact, the skin condition of consumers varies. While other attributes are proactively responding to consumers (20), in fact, still rated low by consumers. Consumers have certainly felt the performance of PT. RRL marketing mix, they feel that two-way communication between companies has not met their expectations when responsive response and when serving consumers is another critical point to bind consumers. Limited human resources are one of the reasons, at PT RRL, the marketing director takes complete control of marketing activities. 


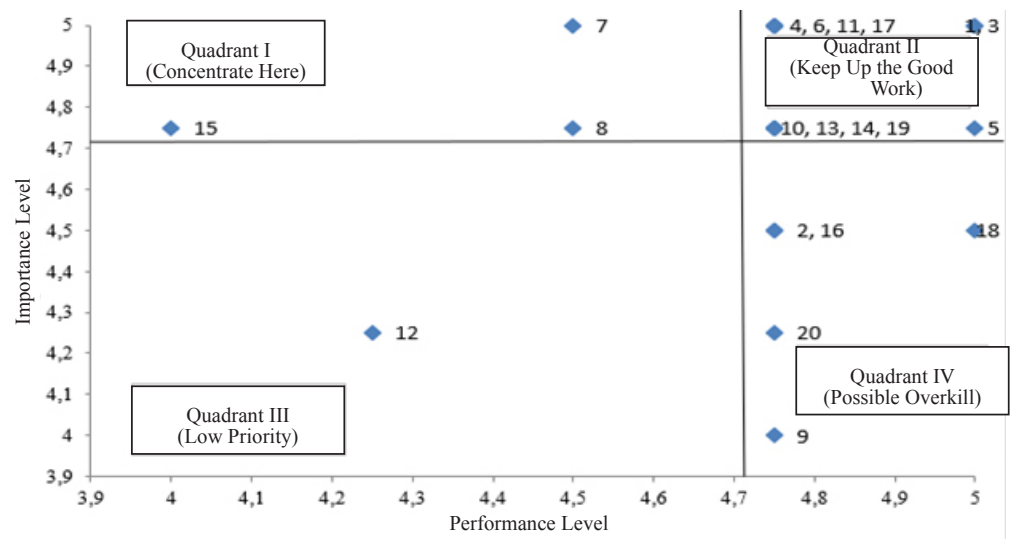

Information:

\section{Quadrant I (First Priority)}

(7) Product safety

(8) Product size variants

(15) Membership tier

\section{Quadrant II (Maintain Achievement)}

(1) Boom product distribution license

(3) Product base materials

(4) Product benefits

(5) Innovative products

(6) Conformity of product variants with skin type

(10) Product packaging facilitates the use of products

(11) Product packaging facilitates product storage
(13) Price conformity with consumer purchasing power

(14) Competitive prices

(17) Ease of finding products online

(19) Communication platform between consumer-company

\section{Quadrant III (Low Priority)}

(12) Product-specific package range

Quadrant IV (Redundant)

(2) Halal certification of products

(9) Product packaging

(16) Ease of finding products offline

(18) Communication containers between consumers

(20) Proactively respond to consumers

Figure 3. Internal company category

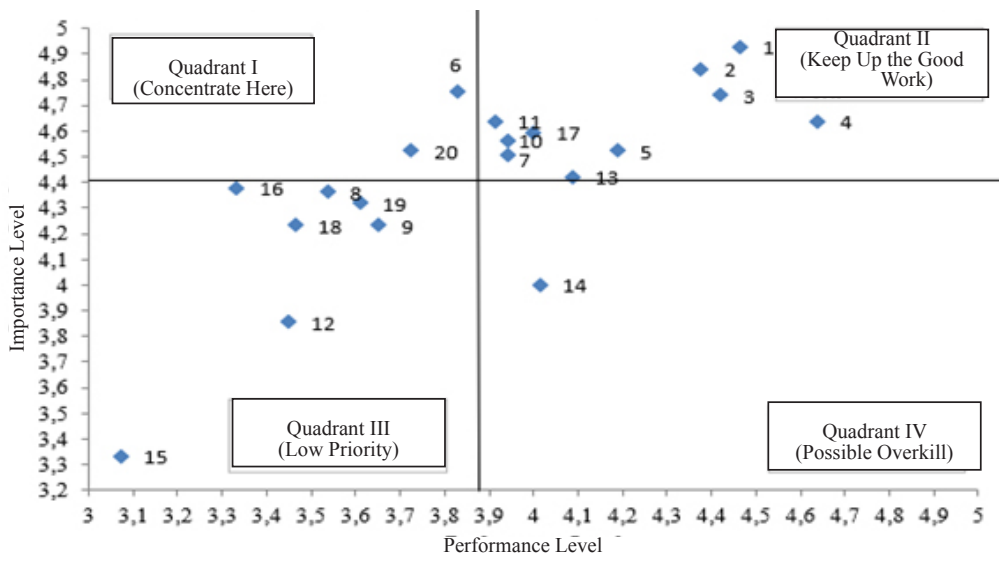

Information:

Quadrant I (First Priority)

(6) Conformity of product variants with skin type

(20) Proactively respond to consumers

Quadrant II (Maintain Achievement)

(1) BPOM distribution permit

(2) Halal certification of products

(3) Product base materials

(4) Product benefits

(5) Innovative products

(7) Product safety

(10) Product packaging facilitates the use of

(11) Product packaging facilitates storage
(13) Price conformity with consumer purchasing power (17) Ease of finding products online

Quadrant III (Low Priority)

(8) Product size variants

(9) Product packaging

(12) Product-specific package range

(15) Membership tier

(16) Ease of finding products offline

(18) Communication containers between consumers

(19) Communication platform between consumer-company

Category IV (Excessive)

(14) Competitive prices

Figure 4. Consumer category 


\section{Potential Customer Category}

This research focuses on improving the attributes that need to be improved, therefore focus on quadrant I. In quadrant I, the level of interest in cosmetic products is above average, while the performance level of PT RRL is still below the average, which means the performance attributes of PT RRL's marketing mix have not met the wishes of potential customers (Figure 5). Therefore, in this quadrant are attributes that become a priority to be improved in order to attract potential customers. Attributes included in quadrant $I$ is the suitability of product variants with skin types (6); just like consumer assessment, potential consumers who have different types of skin, in fact, expect cosmetic products with variants that match their skin type so that the product works optimally. The use of variants that do not match the skin type can cause irritation or incompatibility; potential consumers will also look for other products that suit their skin type. The next attribute is that product packaging facilitates the use of products (10), where potential customers turn out to have higher expectations for product packaging that can facilitate the use of products; this indicates that existing product packaging is considered potential customers are not practical in their use.
Based on the evaluation carried out by the internal company, consumers, and potential customers, the results show that what has been done by the internal party is not following what the consumers and potential customers expect. Based on the level of importance, some attributes are considered most important by the company but not by potential consumers and potential customers (Table 3 ). This shows that in its business activities, the company is running in accordance with its idealism (innovation-driven), as seen from the difference in interests towards what consumers and potential customers want.

\section{Benchmarking Analysis}

Benchmarking is a continuous measurement process and compares one or more company business processes with the best companies in the business process. Benchmarking is done to obtain information that can help companies identify and implement business process improvements. Andersen and Pettersen (1996) explain the stages of the benchmarking process consisting of plan, search, observe, analyze, and adapt.

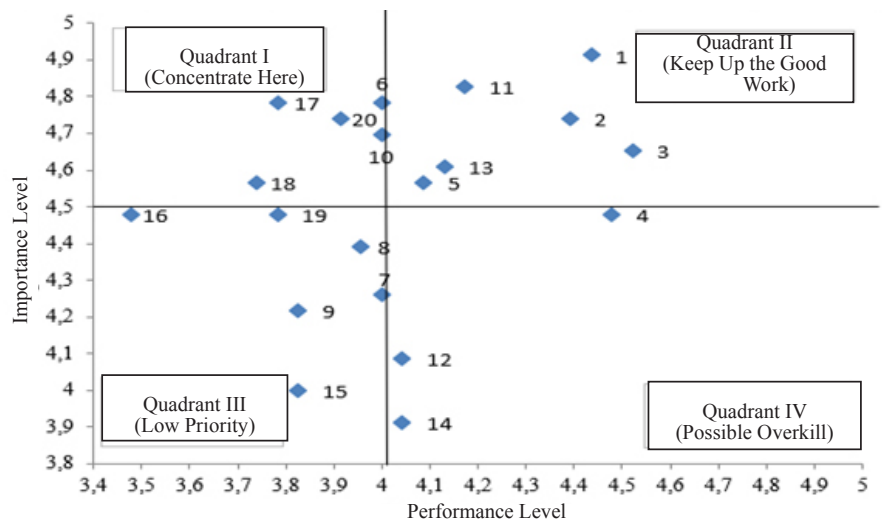

Information

\section{Quadrant I (First Priority)}

(6) Conformity of product variants with skin type

(10) Product packaging facilitates the use of products

(17) Ease of finding products online

(18) Communication containers between consumers

(20) Proactively respond to consumers

Quadrant II (Maintain Achievement)

(1) Boom product distribution license

(2) Halal certification of products

(3) Product base materials

(5) Innovative products

(11) Product packaging facilitates product storage
(13) Price conformity with consumer purchasing power

\author{
Quadrant III (Low Priority) \\ (7) Product safety \\ (8) Product size variants \\ (9) Product packaging \\ (15) Membership tier \\ (16) Ease of finding products offline \\ (19) Communication platform between consumer-company
}

Quadrant IV (Redundant)

(4) Product benefits

(12) Product-specific package range

(14) Competitive prices

Figure 5. Potential customer category 
Table 3. Comparison of IPA priority attribute

\begin{tabular}{|c|c|c|c|}
\hline Marketing Mix & Internal & Consumer & Potential Consumers \\
\hline \multirow[t]{2}{*}{ Co-Creation } & Product safety & $\begin{array}{l}\text { Suitability product variants } \\
\text { with skin types }\end{array}$ & $\begin{array}{l}\text { Suitability product variants with skin } \\
\text { types }\end{array}$ \\
\hline & Product size variants & & $\begin{array}{l}\text { Product packaging makes it easy to use } \\
\text { the product }\end{array}$ \\
\hline Currency & Membership level & - & - \\
\hline Communal Activation & - & - & Ease of finding products online \\
\hline \multirow[t]{2}{*}{ Conversation } & - & $\begin{array}{l}\text { Proactively respond to } \\
\text { consumers }\end{array}$ & $\begin{array}{l}\text { Communication forum between } \\
\text { consumers }\end{array}$ \\
\hline & & & Proactively respond to consumers \\
\hline
\end{tabular}

The formulation of MVM design in this study was formed by evaluating the marketing mix, the current state of the company, and the benchmarking. In this research, benchmarking was carried out with Ocean Fresh. The comparison conducted in this study is benchmarking based on the similarity of one of the product lines, namely body care, which these two companies are in the same industry. Ocean Fresh has been present and has had many customers. Therefore, this company is considered superior because it has had many experiences in conducting its business. Ocean Fresh is also a company with college innovation products engaged in the cosmetics industry by utilizing seaweed as its base ingredient and succeeded well received by the market. Ocean Fresh also has some philosophies that are in line with PT RRL's mission vision, such as empowering seaweed farmers, producing non-food natural zero waste products, and being proud of local products.

Benchmarking analysis was performed by comparing the priority attributes of the IPA calculation results. Results showed four strategic inspirations that PT RRL needs to build and pay attention to. Ocean Fresh is the brand chosen for comparison in this study. CV Ocean Fresh is a university innovation-based company that produces marine polysaccharides (carrageenan, chitin, chitosan), marine bioactive compounds, and derivative products (food and body care).

Based on the results of benchmarking on CV Ocean with a focus on $4 \mathrm{C}$ criteria, several things must be followed up by PT. RRL is as follows:

1. In increasing the value that involves consumers, Wedlyn needs to take advantage of digital media to accommodate various consumer ideas/suggestions.

2. Strategies to maintain loyalty through a membership
3. Activating Wedlyn Community

4. Establishing effective communication with consumers through various company resources

If we look more closely, those four strategies from the column Things Need to be Followed up' can be integrated into one strategy chart that supports forming a Minimum Viable Marketing framework for PT RRL. One of these strategies is named The BCD (Beauty platform, Creative content, Digital community) Strategy (Figure 6).

Based on the picture above, it can be explained further regarding the strategy to facilitate the evaluation of PT RRL's marketing mix as follow:

1. Wedlyn Beauty Platform is used to communicate the values and products of PT RRL and build two-way communication between companies and consumers. The platform can be in the form of a website, social media, or application. This platform must be interactive, provide an experienced mindset for consumers, and build relationships between companies and consumers and between consumers themselves.

2. Enrichment of creative content to support Wedlyn Beauty Platform. This creative content is the main content in various platforms owned by PT RRL. Content can be in writing such as articles or blogs, images such as photos, audio such as podcasts, or videos such as vlogs. Polls, question and answer sessions can be included as another way of creating consumer engagement. Hence, content should be made as creative as possible and in accordance with the market segment.

3. Strengthening the Wedlyn Digital Community is important so that companies do not misunderstand consumers' desires as expressed in the findings of this study; a medium of communication of companies 
and delivery of various offline and online events to consumers. The expected goal is a strong and stable community where members have close relationships with one another, formed naturally through various digital platforms to enhance consumer loyalty. Loyal consumers in a community will be proactive in following the latest information related to the brand (Giddens, 2002).

\section{Minimum Viable Marketing Strategy}

Minimum Viable Marketing (MVM) is a framework for sustainably marketing a business. The MVM framework can build a marketing foundation for a business, select and prioritize channels to reach consumers, and achieve the vision of a business (Johnson, 2018). By looking at the strategy results based on IPA evaluation and benchmarking, the design of PT RRL's MVM must support the increase of marketing mix on co-creation, communal activation, currency, and conversation variables. Additionally, the MVM's framework must cover The BCD Strategy (Figure 7).

\section{Website}

Website is the main foundation of PT RRL's MVM. The website can be interpreted as the face of the company. Important things that must be considered on a website are communicating why the business is unique, delivering detailed information about what kind of business is being run, providing contact information, third party validation, and clear directions in ease of use (Johnson, 2018). Detailed information about what kind of business is being run should contain information about the company and the products it sells. Currently, PT RRL already has a website, but it is inactive, so it needs to be repaired. Website content must fully describe the company's values, various products, advantages, relevant links, and company contacts. The website can be linked to various social media owned by consumers to make it more interactive.

\section{Reliving e-mail marketing}

E-mail marketing is a marketing medium that has functions to promote products and provide companyrelated information via e-mail. This method is effective and simple compared to sending brochures and coupons one by one to consumers. In addition, e-mail can also serve as an invitation to consumers for upcoming events. A comparison company, Ocean Fresh, has utilized e-mail marketing in its business where a special column to subscribe information of the company via e-mail is available on their website. This, of course, can help Ocean Fresh to reach and communicate with its consumers quickly. In fact, PT RRL has provided an e-mail subscription feature on its website, but it has not been used properly. Therefore, the use of e-mail marketing needs to be transformed.

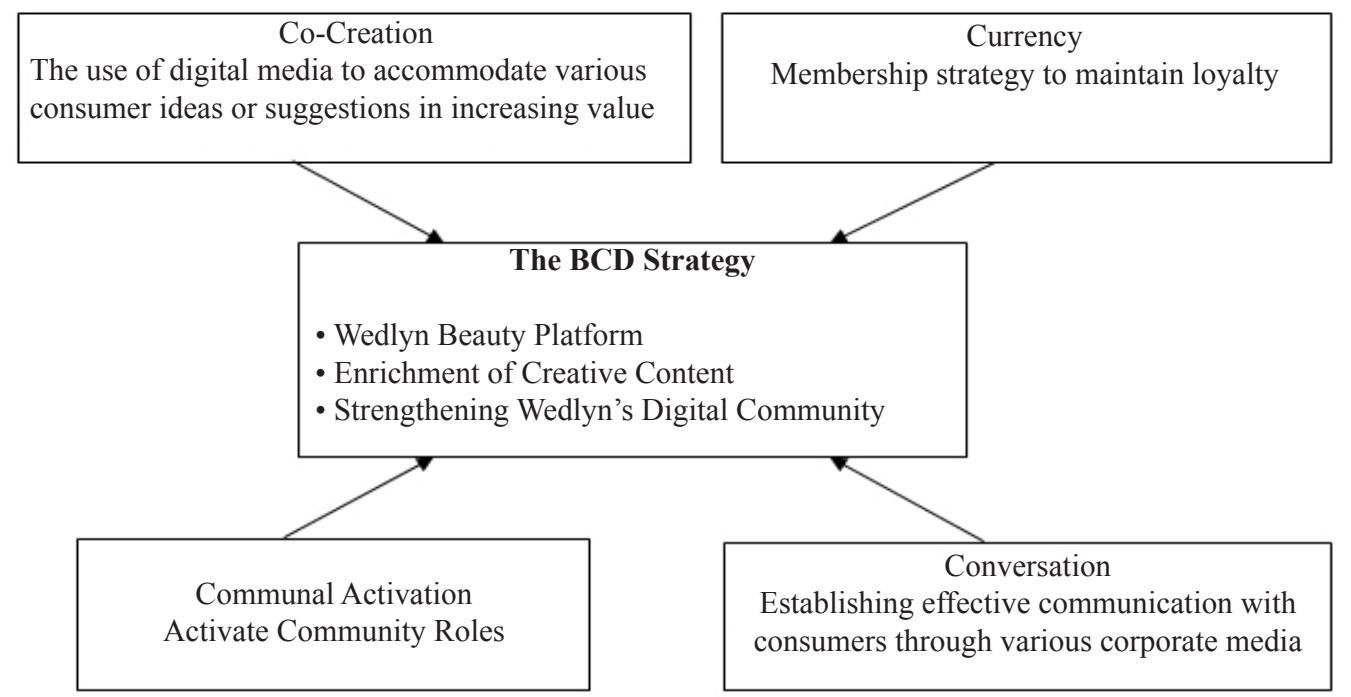

Figure 6. The BCD Strategy 


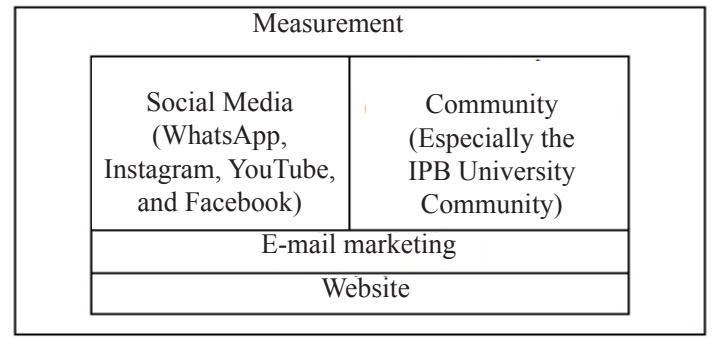

Figure 7. PT RRL's MVM Framework (Jonhshon, 2018)

Amplification channel with the use of social media as a means of communication.

Through social media, marketers can find out the habits of their consumers and interact personally and build deeper bonds (Puntoadi, 2011). In this study, social media used as communication mediums for increasing sales were YouTube, WhatsApp, Instagram, and Facebook. The four social media were chosen because of their high penetration in Indonesia (Hootsuite, 2020). Consequently, most consumers and potential consumers know Wedlyn from social media. For this reason, PT RRL needs to plan its social media content. As content is important, PT RRL needs to create suitable social media content for its consumer segment, has the same tone, is interesting, and is interactive. It means PT RRL does not always do direct marketing but also builds engagement with its followers to form a solid community successfully.

Based on the readiness of social media that Wedlyn owned, WhatsApp is the first medium used to communicate with consumers. Through WhatsApp, PT RRL is following up on various orders from resellers and end consumers. The second social media is Instagram. So far, Instagram has been at the forefront of the amplification channel used by companies. Wedlyn's Instagram was created in June 2017 and currently has 1,760 followers with 246 uploads. For the third social media YouTube, PT RRL already has its channel under PT. Seaweed House. The channel has 42 subscribers and 12 videos uploaded with an average number of views below 100 times; the last video was uploaded one month ago and previously went on hiatus for one year. Not all of the contents were produced by PT RRL; some snippets from the television program were participating. Lastly, PT RRL created a Facebook page for the fourth social media and has 507 followers. The last content on its page was uploaded in 2019. Meanwhile, phone and computer application is the only platform that PT
RRL has not yet owned. Given its importance, which can bring additional value in marketing: building brand awareness and strengthening community involvement, the readiness to establish application needs to be thought out carefully and in detail so that business processes can be captured properly.

\section{A platform dedicated to reviewing.}

Electronic Word of Mouth is an important place for consumers to provide opinions and approaches that are more effective than word of mouth because of accessibility and wider reach than traditional offline media word of mouth (Jalilvand, 2012). With the advancement of internet technology, the World Wide Web-based word of the mouth known as the Electronic Word of Mouth (eWOM) has become widely available. Based on Wardani's (2017), the influence of eWOM at the online forum Female Daily Network on consumers' purchase decisions of Purbasari products, especially among women, is categorized as strong. From these case studies, it can be concluded that the potential consumers, especially women, pay close attention to product reviews before finally deciding to buy cosmetic products. Based on what the comparison companies have done, PT RRL can explore a platform specialized for beauty-product reviews as a medium of communication between consumers. Consumers can also share product reviews, so potential customers who want to know about the product get an overview.

\section{Digital Community.}

When the company already has sufficient resources to do wider marketing, the company can take advantage of the digital-based community as an amplification channel, namely Wedlyn Digital Community, to hold events. Events can be carried out online or offline by PT RRL itself or with other companies. Communities in digital form will certainly have a wider scope. This has its advantages, such as facilitating promotion in self-promotion, which makes the community a channel for research and getting more consumers. To build a community, the company needs to provide values in line with consumers and build deep relationships, not only one-way relationships. A comparison company, Ocean Fresh, has utilized the community for creating events. They become a source for certain materials and a venue for product introduction. The event that is carried out must also be by their vision and mission. 
Furthermore, their community can take advantage of the community within IPB or the general public who have great influence and share the same principles and values.

According to the findings of IPA, namely 'proactively responding to consumers,' the activeness of PT RRL managers is the key to answer consumer expectations. Today, carrying out marketing activities instinct-only is not applicable. Calculation of measurement is required to stay on track (Johnson, 2018). Therefore, the company needs to calculate the results periodically to ensure the effectiveness of foundation and amplification channels and how the company's marketing progresses when carrying out the MVM strategy. The calculation can be done only once a month regularly, and if the pattern has been found, it will make it easier for PT RRL to increase marketing in the future.

The strategy has given above certainly aims to retain consumers and reach a wider range of potential consumers so that they do not hesitate to buy Wedlyn. This strategy is also designed by utilizing technologybased resources owned by the company. It is hoped that the product brand, namely Wedlyn, and the company, namely PT RRL can be better known by the wider community and stored in the minds of consumers so that their marketing plan can run well. The company can survive as well as gradually developing its business.

\section{Managerial Implications}

From this study, it was found that the business process undertaken so far by the company is still based on the idealism of the company (innovation-driven), as seen from the difference in the assessment of the level of importance and the level of performance of internal parties with consumers and potential consumers. The managerial implication of this research is PT. RRL can be more open to new marketing strategies involving consumers and potential consumers more broadly. Through marketing strategies involving consumers, PT. RRL can better understand the consumer's desire so that the products offered are demand-based. PT. RRL can sell its products sustainably and certainly increase sales.

\section{CONCLUSIONS AND RECOMMENDATIONS}

\section{Conclusions}

Based on the evaluation carried out by the internal company, consumers, and potential customers, the results show that what the internal party has done is not under what the consumers and potential customers expect. Based on the level of importance, there are attributes that are considered most important by the company but not by consumers and potential customers, and vice versa. This shows that the company runs by its idealism (innovation-driven) as seen from differences in interests and fails to understand what consumers and potential customers want in its business activities.

The things that PT RRL must improve regarding the marketing mix assessed by consumers and potential customers should focus on co-creation, communal activation, and communication. For this reason, the Wedlyn Beauty Platform's development strategy, creative content enrichment, and the strengthening of the Wedlyn Digital Community are the aims of MVM development.

The design of PT RRL's Minimum Viable Marketing begins with the activation of website and e-mail as marketing foundations, supported by amplification channels which consist of activating social media (WhatsApp, Instagram, Facebook, and YouTube) and digital communities. Measuring the effectiveness of each amplification channel needs to be done regularly to evaluate the increased effect of PT RRL's marketing.

\section{Recommendations}

Based on the research that has been done, the recommendations of this research include:

1. For internal parties PT RRL, should immediately apply the strategy given in this research and do not have to wait for every element on the foundation or amplification channel to be perfect because it is worried that it will be left behind by what is there. So that over time, the minimum viable marketing company can be improved slowly to achieve perfection.

2. Due to the limitations of this study, further research can analyze consumer satisfaction after implying the strategy that has been given in this study to evaluate what has been done by the company. 


\section{REFERENCES}

Afianti IN. 2019. Strategi pemasaran PT. Intidaya Agrolestari (Inagro) di Kabupaten Bogor, Jawa Barat [skripsi]. Bogor: Institut Pertanian Bogor.

Ameka I, Dhewanto W. 2013. Technology push and market pull-in the technology university innovation commercialisation case study ITB. Information Management Business Review 5(7):337-341. https://doi.org/10.22610/imbr. v5i7.1060.

Andersen B, Pettersen P. 1996. The Benchmarking Handbook. London: Chapman.

Aziz R. 2019. Pengembangan strategi pemasaran pada Kedai Teh Laresolo [skripsi]. Bogor: Institut Pertanian Bogor.

Ali M, Ilyas M, Rehman CA. 2016. Impact of consumercentric marketing mix elements on customer buying behavior: An empirical investigation in context of FCMG industry of Pakistan. Kuwait Chapter of Arabian Journal of Business and Management Review 5(5):30-42. https://doi. org/10.12816/0019028.

Giddens N, Hofmann A. 2002. Brand loyalty. http:// www.extension.iastate.edu/agdm/wholefarm. [16 Jun 2020].

Hootsuite. 2020. Social media trends 2020. https:// hootsuite.com/id/research/social-trends. [16 Jun 2020].

Irawati L. 2013. Pengaruh komposisi masker kulit buah manggis (Garcinia mangostana l) dan pati bengkuang terhadap hasil penyembuhan jerawat pada kulit wajah berminyak. E-Journal 2(2):4048.

Johnson BC. 2018. Minimum Viable Marketing: Find the Right Pieces to Build Your Marketing
Strategy. Colorado: New Leaf Educational Solutions.

Jalilvand MR, Samiei N. 2012. The effect of electronic word of mouth on brand image and purchase intention: An empirical study in the automobile industry in Iran. Marketing Intelligence 30(4):460-476. https://doi. org/10.1108/02634501211231946.

Kotler, Keller. 2009. Manajemen Pemasaran. Ed. ke13. Jakarta: Erlangga.

Kotler P, Kartajaya H, Setiawan I. 2017. Marketing 4.0: Moving from Traditional to Digital. Hoboken: Wiley.

Martilla JA, James JC. 1977. Importance-performance analysis: An easily-applied technique for measuring attribute importance and performance canfurther the development of effectivemarketing programs. Journal of Marketing 41(1):77-79. https://doi.org/10.1177/002224297704100112.

Puntoadi D. 2011. Meningkatkan Penjualan Melalui Media Sosial. Jakarta: Gramedia Pustaka Utama.

Wardani AK. 2017. Pengaruh electronic word of mouth pada forum online female daily terhadap minat beli produk Purbasari di kalangan remaja wanita. Jurnal Online Mahasiswa Fakultas Ilmu Sosial dan Ilmu Politik 4(2):1-15.

Widiastuti MP. 2012. Analisis faktor-faktor yang mempengaruhi keputusan penggunaan produk perawatan kulit (Studi kasus pada konsumen di DKI Jakarta) [tesis]. Depok: Sekolah Program Pascasarjana, Universitas Indonesia.

Wijayanti T. 2017. Marketing Plan! dalam Bisnis. Jakarta: PT Elex Media Komputindo. 